\title{
Olympic talent
}

Fit...for nothing?

\section{Richard A. Lovett}

Michael Hood's quest for the 2068 Olympics began when he was six weeks old. Of course, it wasn't 2068 at the time. It was 2041, and Michael's parents were getting a routine assessment of his GeneChievement profile.

"Your son shows high athletic potential," the paediatrician said. "But he'll be even better if we fine-tune his gene expression a bit. What would you like him to be good at?"

"Not football," said his father, whose sports career had ended in a three-way collision between himself, the East Binghamton striker and a fan carrying something that appeared to be a tuba. "How about basketball?"

"Sorry, growth hormone is prohibited. I was thinking about muscles."

There are two types of fibres, the doctor explained, one for endurance, one for strength. "Unless we do something, he's going to have about half of each, which isn't ideal for much except football. You're better to shift it one way or the other. All it takes is a hormone shot. One way he's a sprinter or weightlifter, the other he's a long-distance type."

That was easy. Michael's father had fond memories of the days before the tuba, when he could run for ever and never get tired.

"Can you make him tough, too?"

"Sure." The doctor sneaked a peek at his palm computer and pulled up a folder labelled neurotransmitters. "How competitive would you like him to be?”

Time did its usual thing and the boy grew. $\mathrm{He}$ ran through woods and fields. He climbed trees and fell out of them because although he was whippet-thin and fast, feats of strength eluded him.

It was during one of his periodic stints in hospital that another doctor visited. "They didn't give you enough strength," the new doctor said. "But we have a technique for dealing with that. Actually, you're lucky. The sports authorities allow us to fix mistakes if people were improperly modified first time around. We can make you better than if they'd gotten it right back then. It's painless, but it uses a virus to reprogramme your muscle cells, so you might feel a bit under the weather for a few days."

Soon, Michael was both strong and fast - although at first that simply helped him find more sophisticated (or not-so-sophisticated) ways to show off. When he was 16 , after a particularly bad brush with gravity involving a flexboard and a blonde, yet another doctor visited, with an older man in tow.

"They certainly got the toughness part right," this doctor said. "Unfortunately, the same neurotransmitters can make you stupid."

"I get good marks!"

"Not that kind of stupid." The doctor gestured to his guest. "This is Coach Brooks. Sports are changing, largely thanks to genetweaked kids like you. He'll show you how to avoid spending so much time in here."
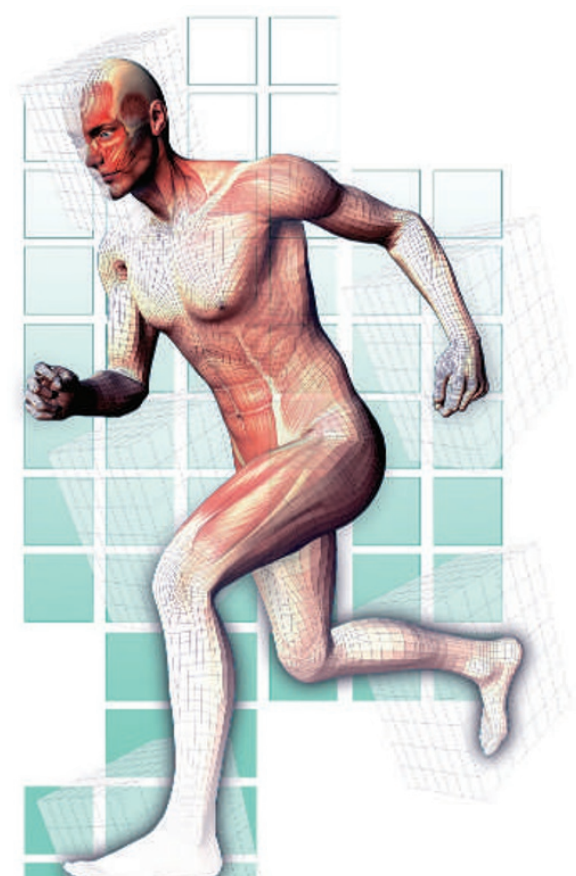

The 'how' turned out to be virtual reality.

"There's no longer any need to risk getting hurt," the coach said. "I can set you up with a sensory-feedback suit in which you can be as competitive as you like without leaving home. Once you get used to it, you'll barely know the difference."

He turned to Michael's father. "It's perfectly safe. He could try triple flips on a flexboard and land on his head, and it would merely give him a bit of a thump. Not that I'm going to teach him flexboard tricks. He's always had running talent; if he's not hurt all the time, he can be really good. By the time he's in his prime, VR will be an Olympic sport."

Coach Brooks was wrong about one thing. By the time Michael was ready, virtual reality wasn't just part of the Olympics, it was the Olympics. There was no need to build a stadium, no need to travel - although there was a bit of hubbub at first about the certification of VR stations to avoid secret... improvements.

Michael turned out to be as good as anyone could wish. He chose to double in the 5,000 and 10,000 metres, jostling elbows in the pack at the start, then pulling away with two others in what was ultimately a test of whose gene doctor had found the optimal mix of muscles and neurotransmitters.

Toughness triumphed and Michael, straining in his climate-controlled suit thousands of kilometres from his rivals, pulled through to double gold. He only wished hed gone for the triple and added the marathon to the mix.

Then it was over. Coach Brooks came and took back the suit because Michael would be too old to make another go for gold four years later. Besides, there was a cadre of even better gene-crafted athletes coming up behind him.

He was famous, but nobody knew his face because the icon he'd worn in the games belonged to an even-more-famous musician - picked, of course, to be recognizable to the millions thronging the virtual grandstands.

One day, Michael found himself in a park, watching joggers. He'd bought a pair of shoes - his first real ones in years - so he laced them up and fell in behind a young woman who had programmed her shirt to display his Olympic icon crossing the finish.

Unfortunately, Coach Brooks had been wrong about another thing: VR wasn't quite the same as real running. Superbly trained for one, but not the other, Michael laboured just to keep the woman from pulling away.

But he still had his gene-tweaked toughness. And the woman was not only surprisingly good for a recreational runner, she was pretty. Michael's social skills were a bit rusty, but the shirt said that if he could catch her, she'd be easy to talk to. Pushing hard to catch up while trying to make it look easy, he wondered: if he and a natural athlete like her hit it off and found the right doctor, could their child win the triple? Richard A. Lovett is a four-time winner of Analog science-fiction magazine's AnLab reader's choice award. He also writes for New Scientist, National Geographic News and Running Times, and is a coach and co-author of two running books with marathon great Alberto Salazar. 